\title{
Biodegradation of Benzidibe by Alkaliphilic Strain Bacillus badius D1
}

\author{
V.D. Sarwade \\ Jamkhed College Jamkhed. Department of Chemistry (MS) India.
}

\begin{abstract}
Benzidine biodegradation was studied for $48 \mathrm{hr}$. using Bacillus badius D1. Various concentrations ranging from 100 to $500 \mathrm{mg} / \mathrm{L}$ of benzidine were used to judge the biodegradation percentage. The effect of different parameters like $\mathrm{pH}$, temperature, salinity, carbon and nitrogen sources was also studied. The enzyme activities of certain biotransformation enzymes like CYP450, SOD, Acetanilide hydroxylase, Aminopyrine $\mathrm{N}$ demethylase were carried by standard methods and were found induced during biodegradation. Complete degradation observed at $100 \mathrm{mg} / \mathrm{L} .92 \%$ benzidine $(500 \mathrm{mg} / \mathrm{L})$ was degraded at $32{ }^{\circ} \mathrm{C}, \mathrm{pH} 9.00$ in shaking incubator with $110 \mathrm{rpm}$.
\end{abstract}

Key Words: Biodegradation, Benzidine, Bacillus badius DI

Abbreviations: SOD-Superoxide dismutase, CYP450-Cytochrome P450

\section{Introduction:}

Benzidine is a toxic aromatic amine. It causes the bladder cancer in mammals. Azo dyes account for the majority of all textile dyestuffs produced and are the most commonly used in synthetic dyes, textiles, and paper industries. These are also used in printing technology leather and cosmetic industries [1]. Many azo dyes on biotransformation turn into benzidine as one of the metabolite of catabolic pathway. It is threat to health due to benzidine induces tumors in the liver of hamsters. It also affected the Harderian gland, Zymbal's gland. Mammary gland, and intestine of rats [2,3]. Other aryl amines structurally related to benzidine induced tumors through alteration in critical cellular constituents by reactive aryl amine metabolites formed within the target organs.

$\mathrm{N}$-Hydroxylation is regarded as the initial step in metabolic activation of these aryl amines and aryl amides; subsequent esterification of the N-hydroxyl moiety yields electrophilic reactants capable of binding to nucleophilic centers in protein, RNA, and DNA. Several biotransformation occurs in benzidine during detoxification. Some of these changes in benzidine appear to cause many of the chemical's harmful effects [4]. The disposal of such dye stuff or aromatics can be carried by aerobic, anaerobic microbes or both in combination. [5, 6,7 ].

\section{Methodology:}

2.1Chemicals: Yeast extract, peptone was purchased from Hi-media Mumbai. Other chemicals were taken from SRL chemicals. Pure bezidine was obtained by the curtsy of Department of Chemistry, Pune University.

\subsection{Composition of the media:}

Yeast Extract $-5 \mathrm{~g} / \mathrm{L}$, Peptone- $5 \mathrm{~g} / \mathrm{L}, \mathrm{NaCl}-3 \mathrm{~g} / \mathrm{L}, \mathrm{KH}_{2} \mathrm{PO}_{4^{-}} 170 \mathrm{mg} / \mathrm{L}, \mathrm{Na}_{2} \mathrm{HPO}_{4^{-}} 290 \mathrm{mg} / \mathrm{L},\left(\mathrm{NH}_{4}\right)_{2} \mathrm{SO}_{4^{-}}$ $100 \mathrm{mg} / \mathrm{L}, \mathrm{MgSO}_{4^{-}} \quad 4.87 \mathrm{mg} / \mathrm{L}, \mathrm{FeSO}_{4^{-}} \quad 0.05 \mathrm{mg} / \mathrm{L}, \mathrm{CaCO}_{3^{-}} \quad 0.2 \mathrm{mg} / \mathrm{L}, \mathrm{ZnSO}_{4^{-}} \quad 0.08 \mathrm{mg} / \mathrm{L}, \mathrm{CuSO}_{4}-0.016 \mathrm{mg} / \mathrm{L}$, $\mathrm{CaSO}_{4^{-}} 0.015 \mathrm{mg} / \mathrm{L}$, Boric Acid-0.006mg/L ,pH 9.00 sterilized by autoclaving at $121{ }^{\circ} \mathrm{C}$ for 20 minutes.

2.3 Biodegradation study: Nine $500 \mathrm{ml}$ Conical flasks containing sterilized $250 \mathrm{ml}$ alkaline broth of pH-9.00 were inoculated by $1 \%$ Bacillus badius D1 culture possessing $1.6 \mathrm{OD}$ at $600 \mathrm{~nm}$ aseptically. These culture flasks were incubated for $24 \mathrm{hrs}$ at $37^{\circ} \mathrm{C}$ with shaking on Orbital shaker at $110 \mathrm{rpm}$. The $24 \mathrm{hrs}$ grown culture flasks were induced by adding appropriate concentration of benzidine. These flasks were removed sequentially from 0 to 48 hours by $6 \mathrm{hr}$. interval. The removed flasks were used for OD at $600 \mathrm{~nm}$ to check the growth and then spun to DuPont Sorvoll Cold centrifuge at 10000 x g. Similarly one another flask was kept as abiotic control by adding experimental concentration of benzidine. All experiments were carried in the dark. The study was extended to verify the effects of various parameters like concentration, $\mathrm{pH}$, temperature, salinity, carbon and nitrogen sources on biodegradation. The bio-catalytic induction of biodegradation was studied by standard methods.

\subsection{Spectrophotometric analysis:}

An aliquot of cell free centrifuged supernatant was used for solvent extraction to know the spectral changes in benzidine at various time intervals and remaining was used to evaluate the concentration remaining after biodegradation using spectrophotometer Jasco Varien 630 at $285 \mathrm{~nm}$. 
2.5 Cytosolic preparation and enzyme activities: Cell mass was harvested after 24 hours induction with benzidine by Du-Pont Sorvall RC-5B centrifuge by spinning at $10000 \mathrm{x} g$ for $15 \mathrm{~min}$ at $4{ }^{0} \mathrm{C}$. The cell mass was washed with phosphate buffer $\mathrm{pH} 8.0$ twice and physiological saline. Cell disruption was carried by sonicator Ultra O Sonic (Mumbai) in Tris buffer $\mathrm{pH}$ 7.50. The resulting homogenate was centrifuged in cold condition at $15000 \mathrm{x} \mathrm{g}$ for $20 \mathrm{~min}$. The protein in cytosole was estimated by Lawry [8]. Cytochrome P450 was determined by Omura and Sato[ 9,10].Superoxide dismutase activity was carried by Mishra and Fredovic [11]. Aminopyrine $\mathrm{N}$-demethylase and Acetanilide hydroxylase activities were performed by Shenkman, Weiseberg and Goodal $[12,13]$.

III. Results:

3.1 Spectral changes observed in Benzidine during biodegradation.

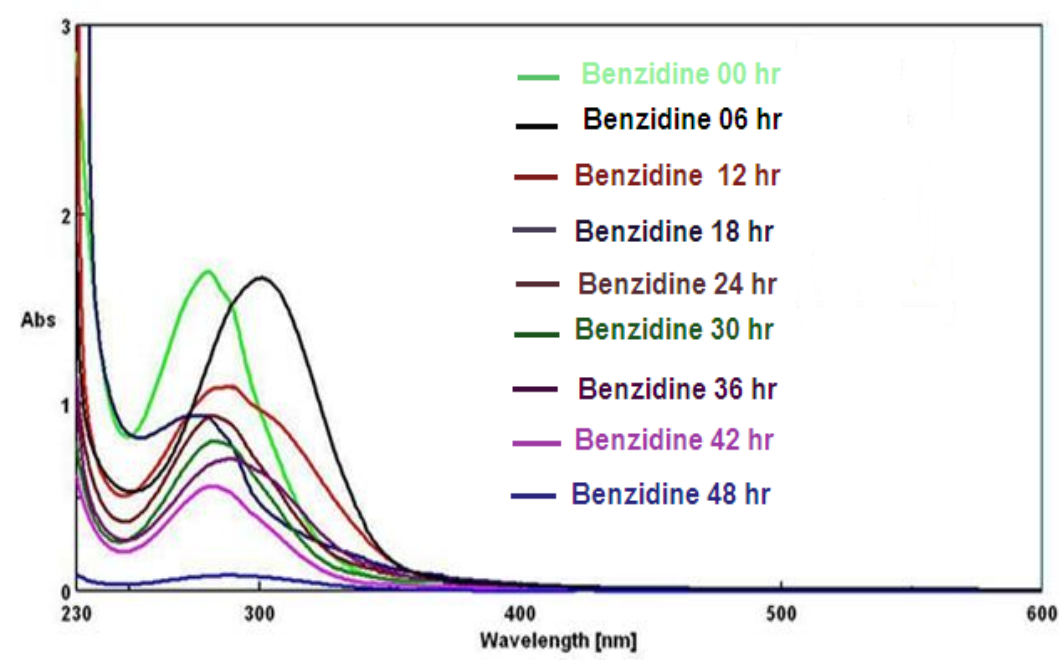

Fig. 1 Spectral changes in Benzidine during biodegrdation by Bacillus badius D1

Spectrophotomrtric determination of benzidine was carried at $285 \mathrm{~nm}$. The initial spectrum $285 \mathrm{~nm}$ shifted to right at $320 \mathrm{~nm}$ which undergone several changes indicated biotransformation in benzidine molecule (Fig.1). Further quantitative analysis was carried by monitoring reduction in absorption at $285 \mathrm{~nm}$.

\subsection{Biodegradation of Benzidine at various concentration:}

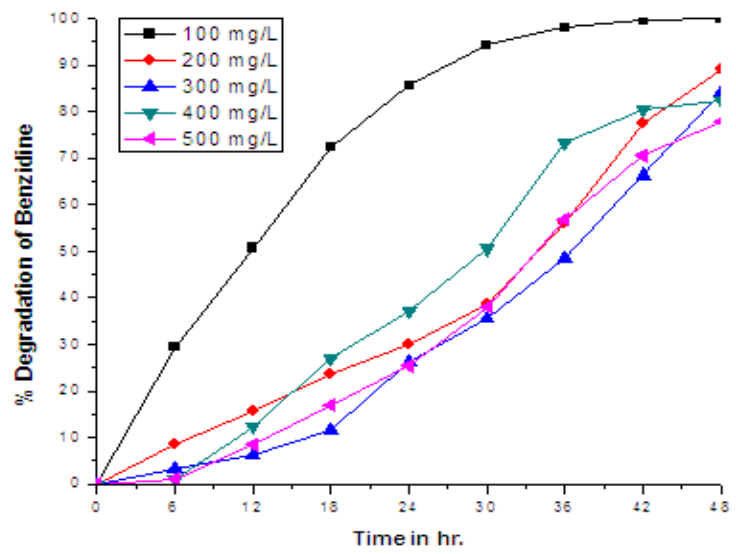

Fig.2 Biodegradation of Benzidine by Bacillus badius D1 at various concentrations

It was observed that after inoculation of benzidine in Bacillus badius D1 in alkaline medium pH 9.00 at $37{ }^{0} \mathrm{C}$ with experimental concentration ranging from $100 \mathrm{mg} / \mathrm{L}$ to $500 \mathrm{mg} / \mathrm{L}$; that the higher concentration negatively affects the percentage degradation (Fig.2). The concentration of benzidine (100 mg/L) was completely degraded within $48 \mathrm{hr}$. It also degraded the higher concentration $(500 \mathrm{mg} / \mathrm{L})$; but the percentage degradation was found $78 \%$ in the same experimental condition. 


\subsection{Biodegradation of Benzidine at various $\mathrm{pH}$ :}

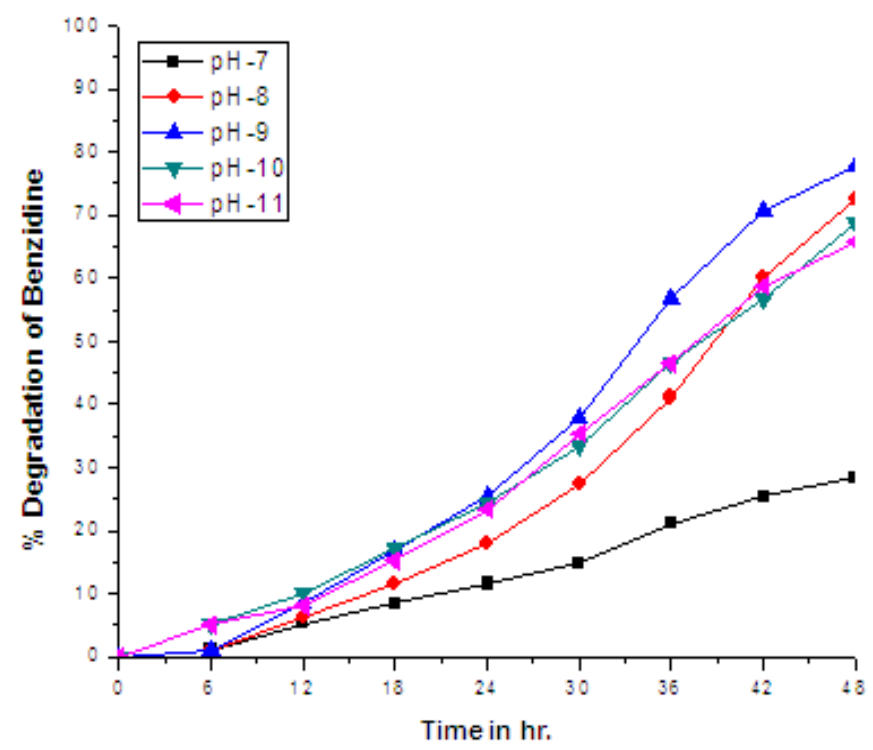

Fig.3 Biodegradation of Benzidine at various $\mathrm{pH}$ by Bacillus badius D1

The effect of $\mathrm{pH}$ on percentage degradation of benzidine was studied at $500 \mathrm{mg} / \mathrm{L}, 37{ }^{0} \mathrm{C}$ in shaking incubator at $110 \mathrm{rpm}, \mathrm{PH}$.ranging from 7.00 to 11.00 . The (fig. 3) shows the optimum $\mathrm{pH} 9.00$ for degradation. Marginal change at $\mathrm{pH} 8.00,9.00,10.00$ and was noted; while the lowest degradation rate was found at $\mathrm{pH} 7.00$.

\subsection{Biodegradation of Benzidine at various Temperatures:}

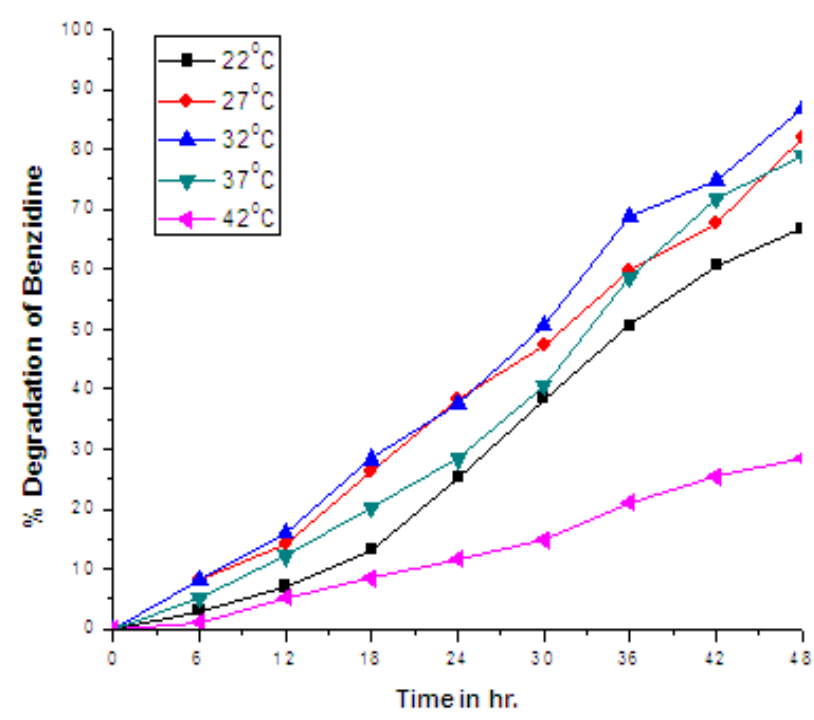

Fig.4 Biodegradation of Benzidine at various Temperatures by Bacillus badius D1

The effect of temperature $\left(22{ }^{\circ} \mathrm{C}-42{ }^{\circ} \mathrm{C}\right)$ on biodegradation of benzidine was studied using Bacillus badius D1. Benzidine was inoculated in fully grown culture of alkaline medium of $\mathrm{pH} 9.00$ and at the experimental condition. The Fig (4) showed that the temperature $32{ }^{\circ} \mathrm{C}$ was positively affected the percentage degradation. Least degradation percentage was noted at $42{ }^{\circ} \mathrm{C}$ 


\subsection{Biodegradation of Benzidine at different Salinity:}

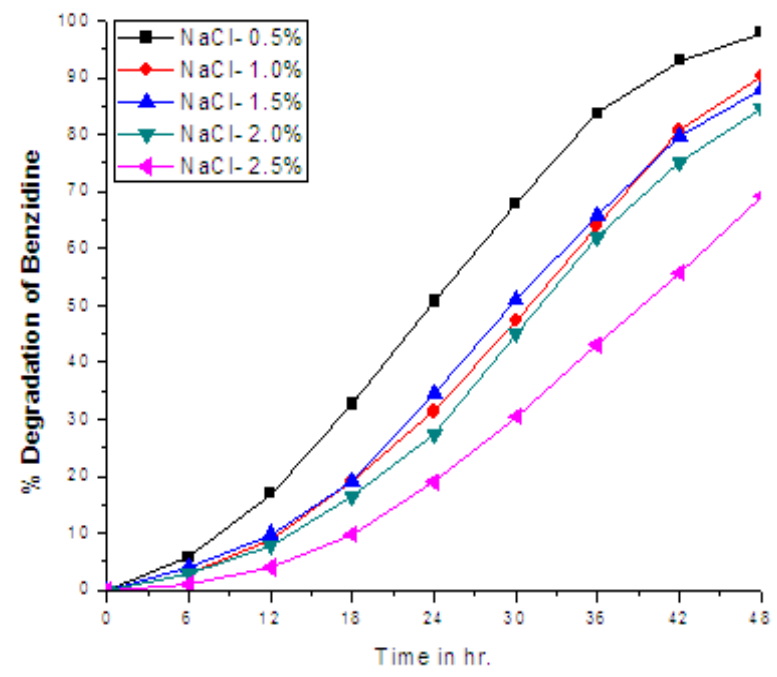

Fig.5 Biodegradation of Benzidine by Bacillus badius D1 at different Salinity

The (Fig. 5) indicate the biodegradtion of benzidine by Bacillus badius D1 at salinity range $0.5 \%$ to 2.5\%. The experimental conditions were same as that of other experimental parameters except salinity difference. It indicated that at $0.5 \%$ salinity, the percentage degradation was high and at higher salinity the percentage degradation was less.

\subsection{Biodegradation of Benzidine with carbon Sources:}

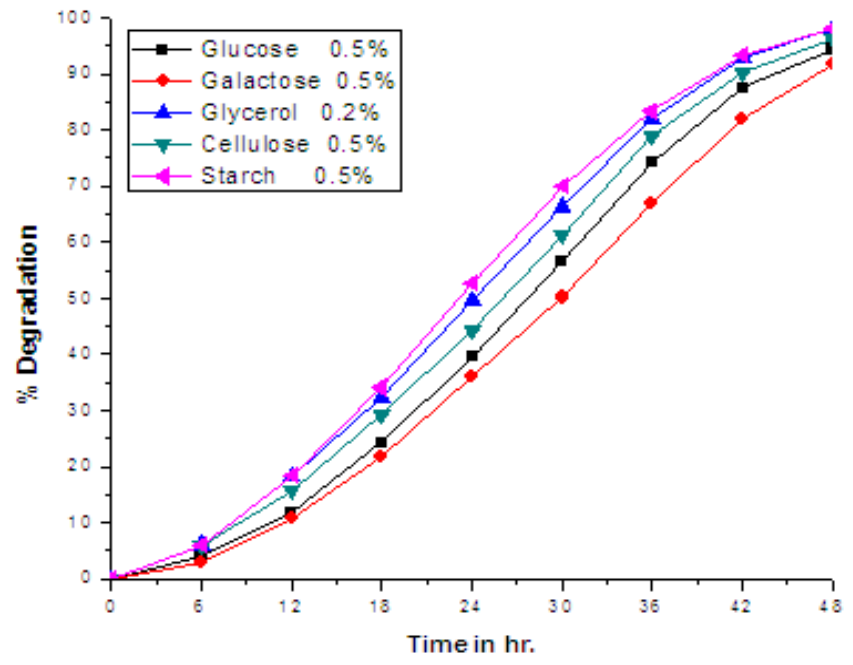

Fig.6 Biodegradation of Benzidine by Bacillus badius D1 using different carbon sources

The (Fig. 6) showed the effect of additional carbon source in the culture medium at similar experimental condition; marginal changes in \% degradation of benzidine by Bacillis badius D1 were noted. 


\subsection{Biodegradation of benzidine at various nitrogen sources:}

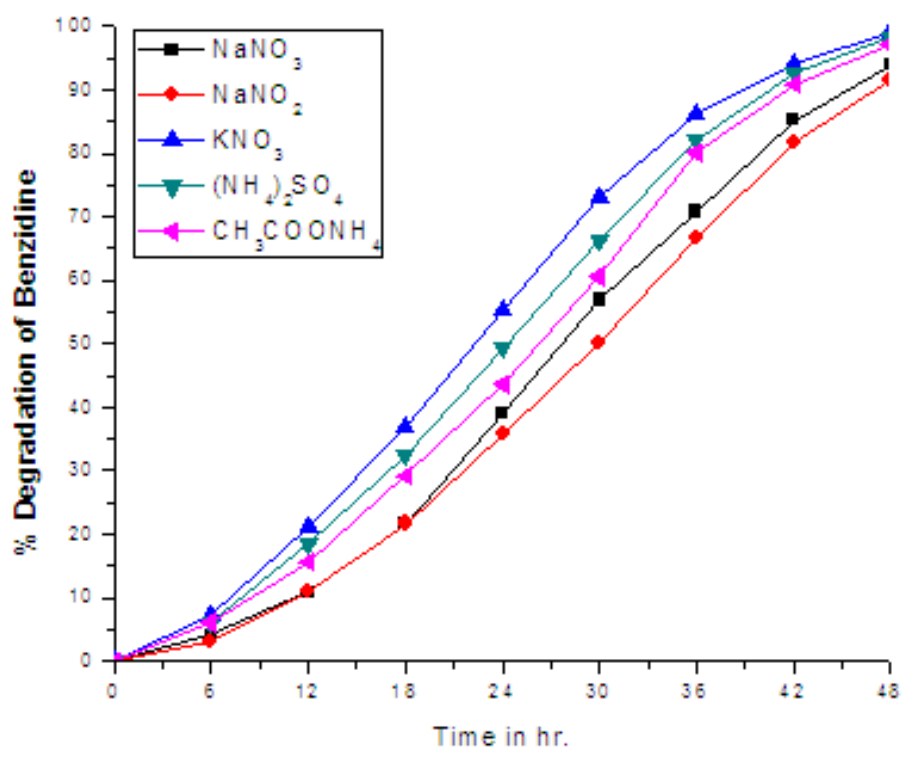

Fig.7 Biodegradation of benzidine by Bacillus badius D1 using various nitrogen sources

The (Fig.7) indicates the percentage degradation of benzidine $(500 \mathrm{mg} / \mathrm{L})$ at various additional mineral nitrogen sources. The addition of $0.02 \mathrm{~g} / \mathrm{L}$ inorganic nitrogen source marginally affected the percentage degradation of benzidine at experimental condition except additional nitrogen sources. Addition of $\mathrm{NaNO}_{2}$ had not stimulated the percentage degradation of benzidine as compaired to other sources but all nitrogen sources positively affected on degradation.

\subsection{Induction of Biotransformation enzymes by bezidine:}

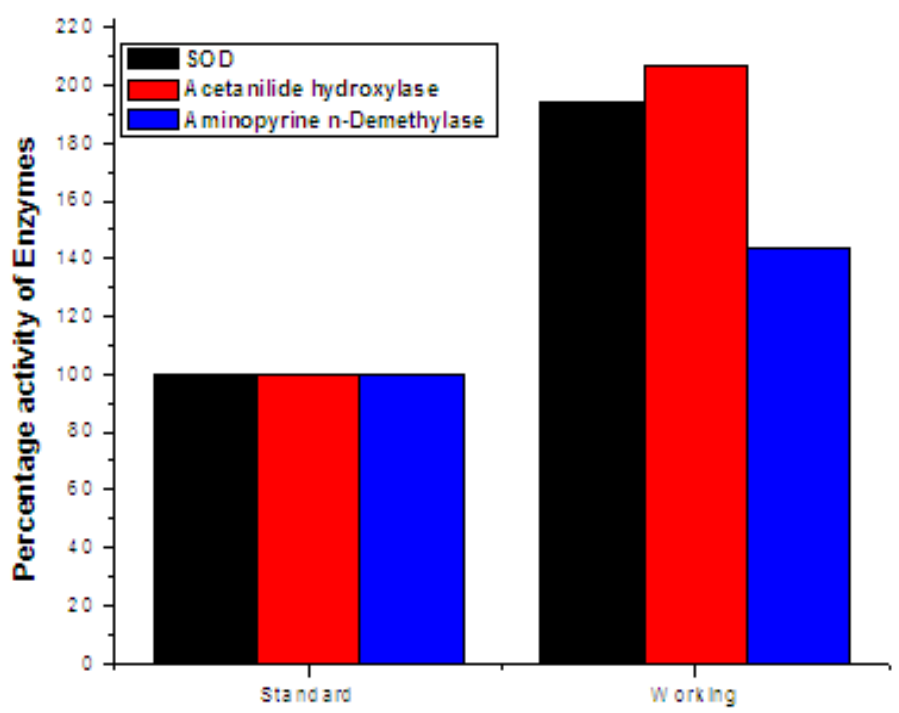

Fig.8 Induction of Biotransformation enzymes in Bacillus badius D1 by bezidine at $24 \mathrm{hr}$.

Cytocrome P450 concentration was found increased $0.06 \mathrm{mg} / \mathrm{ml}$ in experimental flasks compaired to control flask (without benzidine) on induction for $24 \mathrm{hr}$. The enzyme activities of SOD, Acetanilide hyddroxylase and Aminopyrine $\mathrm{N}$-demethalase were carried by standard methods. The (Fig. 8) illustrate the enzymes induced during biodegradation. Acetanilide hydroxylase activity was observed more among all the enzymes studied. 


\section{Discussion}

Environmental pollutants are the substances entering into the environment at higher concentration and exerting toxicity to the living creatures in a specific chemical form at exceeding the threshold limit value [14]. These pollutants or xenobiotic substances are being a serious problem of nature. The xenobiotics like organochlorines, aromatic amine, phenolics, pesticides ,dyes ,drugs, paper and pulp industrial waste or wastes from refineries, distilleries are exerting toxic effects on environment. However, it is believed that microorganisms are capable of degrading almost all the different complex and resistant xenobiotics found on the earth $[15,16]$. Thus environmental wastes have to be treated before they are introduced into the environment. Azo dyes are dominant synthetic dyes which on degradation converts into toxic aromatic amines [17]. Benzidine is one among the aromatic amines produced during biodegradation of such dyes. Swallowing contaminated dust of benzidine can also enter the body by passing through the skin. Some dyes may still contain small amounts of benzidine as a contaminant, or chemicals that may transform to benzidine [18]. Use of such dyes to dyeing cloth, leather, or other materials; one can expose to benzidine by breathing or swallowing dust, through skin contact. Benzidine is recalcitrant compound having carcinogenic, mutagenic and genotoxic effects. [19, 20, 21].

Biotransformation of these recalcitrants can dominate toxicokinetics and the metabolites may reach higher concentrations in organisms than their parent compounds [22, 23, 24, 25]. These recalcitrants can affect normal microflora of soil positively or negatively. Benzidine shown negative effect on the nitrogenase activity of bacteria [26]. The discharge of benzidine dyes into water bodies can causes toxic effects like DNA damage in human beings [27]. Benzidine based dyes affects on mixed function oxidase system [28].

Recent advancements have proved successful via the addition of matched microbial strains to the medium to enhance the resident microbe population's ability to break down contaminants. [29 - 34].Still the reports of contaminant degradation are less in alkaline condition [35,-39].

In current studies Bacillus badius D1 was used for degradation of aromatic amine benzidine. The usual absorption spectrum of benzidine found altered in experimental flask and no change in abiotic control flask containing alkaline broth media of $\mathrm{pH} 9.00$ at $37{ }^{\circ} \mathrm{C}$ at $110 \mathrm{rpm}$ in shaking incubator. This indicates that benzidine had gone through several biotransformation steps. Fig. (1). During the breakdown or detoxification the biotransformation enzymes were increased comparative to control [40]. The Fig (8) showed that Bacillus badius D1 was actively involved in biodegradation process inducing biotransformation enzymes[41]. It is well reputed that effect of particular concentration, temperature, $\mathrm{pH}$, carbon and nitrogen affect significantly on biodegradation [42- 45]. The biotransformation enzyme induction was reported in case of $\gamma$ Proteobacterium and others [46-49].

It was tried to know the maximum percentage degradation of benzidine on inoculation of Bacillus badius D1 culture in alkaline broth possessing different concentration of benzidine ranging from 100 to 500 $\mathrm{mg} / \mathrm{L}$. at 37 0C, $110 \mathrm{rpm}, \mathrm{pH} 9.00$. It was observed that at lower $(100 \mathrm{mg} / \mathrm{L})$ concentration was easily degraded by the bacteria. As the concentration increases the rate of percentage degradation was lowered [50]. Although, there was higher concentration $500 \mathrm{mg} / \mathrm{L}$ benzidine $78 \%$ degradation of benzidine was noticed (Fig.2). To optimize the process of degradation various parameters like $\mathrm{pH}$, temperature, salinity, additional carbon and nitrogen sources also studied.

Benzidine $(500 \mathrm{mg} / \mathrm{L})$ was inoculated with Bacillus badius D1 culture in alkaline broth at various $\mathrm{pH}$, $37^{0} \mathrm{C}, 110 \mathrm{rpm}$ to study the percentage degradation. The optimum $\mathrm{pH}$ for benzidine degradation was recorded $\mathrm{pH}$ 9.00; however Bacillus badius D1 shown broad $\mathrm{pH}$ range from $\mathrm{pH} 7.00$ to $\mathrm{pH} 11.00$ for degradation as in Gig. (fig.3). Some of the bacterial enzymes showed $\mathrm{pH}$ versatility and salt tolerance in azo dye degradation [51]. Thus $\mathrm{pH}$ parameter can affect the biodegradation [52].

Similar to $\mathrm{pH}$ parameter the degradation study for temperature parameter also carried to know the effect on percentage degradation of benzidine by Bacillus badius D1. Marked percentage degradation at $32^{\circ} \mathrm{C}$ was noted. Rest of other temperatures shown little less percentage degradation of benzidine as in (Fig.4). This might be due to negative effect of temperature on biodegradation enzymes.

The (Fig.5) indicate the biodegradation of benzidine by Bacillus badius D1 using different salinity. At $0.5 \%$ salinity $98 \%$ benzidine degradation was noted. Usually $0.3 \%$ salinity was used for other experimental parameters. Excess salinity or less salinity might have bothered the osmoregulation of Bacillus badius D1[53]. Some of the bacteria have high salinity tolerance [54].

Both carbon and nitrogen sources positively affected the biodegradation of benzidine by Bacillus badius D1.Fig (6) and Fig(7).Utilization of additional carbon and nitrogen sources was favored the biodegradation of pollutant in case of Stenotrophomonas maltophila [55]

4.1 Conclusion: Bacillus badius D1 is potent nonpathogenic bacteria isolated from Lonar Crater Lake MS, India is able to degrade carcinogenic and genotoxic contaminant benzidine at higher concentration. Exploiting it to various other aromatic amines can be effective in bioremediation process at contaminated sites. 


\title{
Acknowledgement:
}

\author{
Chemistry Pune. \\ Special thanks to UGC (WRO), New Delhi, India. Prof. Kr.Gawai, University of Pune, Department of
}

\section{References:}

[1]. Ewelina Weglarz-Tomczak, Azo dyes - biological activity and synthetic Strategy, Chemik nr (66),1298-1307, 2012.

[2]. Report on 'Addendum to the toxicological profile for Benzidine', Agency for Toxic Substances and Disease Registry Division of Toxicology and Environmental Medicine Atlanta, GA 30333, 2009 pp-8-18

[3]. Albrecht Seidel, Gernot Grmmer foundation, Bochum Germany, Exposere to aromatic amines- Overview on Chemistry, Biotransformation and possible mode of action, Symposium on Occupation ,Aromatic amines, PAH and Bladder cancer,2009

[4]. Ruth M Lunn, Report on Carcinogens, Twelfth Edition (2011), National Toxicology Program, Department of Health and Human Services,pp-38-41, lunn@ niehs.nih.gov

[5]. Puvaneshwari, Muthukrishnan and Gunshekharan, Biodegradation of Benzedine based azo dyes Direct Red and Direct Blue by immobilized cells of Pseudomonas fluorescence D41, Indian journal of experimental Biology,2002,1131-1136

[6]. Derle Shilpa G. , Patil Niranjan P. and Gaikwad Vishwas, Ecofriendly Biodegradation of Reactive Yellow 145 by newly isolated Bacillus boroniphilus from industrial effluent, Journal of Environmental Research and Development, Vol. 7 No. 1 A, 2012

[7]. P. Arulazhagan; N. Vasudevan; Biodegradation of polycyclic aromatic hydrocarbon by a halotolerant bacterial consortium isolated from marine environment, Int. J. Environ. Sci. Tech., 7 (4), 639-652, 2010

[8]. Lowry H.O, Rosboough, N. j .Farr, A.L. and Randall R.J. „Protein determination by Oliver H. Lowry,Journal of biological chemistry, 193(1951) 265-275.

[9]. Omura T. and Sato T.R., The Carbon Monoxide-binding Pigment of Liver Microsomes, J. Of Biol.Chem , 239 (1964) 2370-2378.

[10]. Suk-Jung Choi, Mira Kim, Sung-Il Kim and Joong-Kyun Jeon, Microplate Assay Measurement of cytochrome P450-Carbon Monoxide Complexes, Journal of Biochemistry and Molecular Biology, 36( 2003) 332-335.

[11]. Misra H.P. Fridivich I, The Role of Super oxide Anion in the autoxidation of Epinephrine and a Simple Assay for Super oxide Dismutase, J. Biol.Chem, 247 (1972) 3170-3175.

[12]. Shenkman J. B Remmer H., Estabrook R.W, Spectral studies of drug interaction with hepatic microsomal cytochrome, Mol Pharmacology, 3(1967)113-123.

[13]. Weisburger and Goodal, Steric inhibition of enzyme reactions. Lack of enzymic hydrolysis of 2, 4,6 trimethylacetanilide, Life Sciences. (1968) 263-268.

[14]. The Chemicals Management Plan Substance Groupings Initiative Aromatic Azo- and Benzidine-Based Substances , Environment, Health Canada July 2012

[15]. Neha Sharma, Vikas C. Gupta, Comparative Biodegradation Analysis of Phenol from Paper \& Pulp Industrial Effluent by Free and Immobilized Cells of Aspergillus Niger, International Conference on Environmental Science and Technology IPCBEE vol.30 (2012) 68-72.

[16]. C. Ma, L. Zhuang, S.G. Zhou, Alkaline extracellular reduction: isolation and characterization of an alkaliphilic and halotolerant bacterium, Bacillus pseudofirmus MC02, Journal of Applied Microbiology ISSN 1364-5072, 2012 pp 1-9.

[17]. Montira Leelakriangsak, Molecular approaches for bacterial azoreductases, Songklanakarin J. Sci. Technol.35 (6), 647-657, 2013

[18]. Amit Bafana \& Sivanesan Saravana Devi \&Kannan Krishnamurthi \& Tapan Chakrabarti, Kinetics of decolourisation and biotransformationof direct black 38 by C. hominis and P. stutzeri, Appl Microbiol Biotechnol 74:1145-1152. (2007) DOI 10.1007/s00253-006-0751-5

[19]. S.C. Chen, C.S. Lin, S.H. Liang and J.Y. Chuang, Detection of gentoxicity of benzidine and its derivatives with the Escherichia coli DJ 702 lacZ reversion mutagenicity assay, Letters in Applied Microbiology ISSN 0266-8254,2006

[20]. 'Benzidine', Agency for Toxic Substances and Disease Registry Division of Toxicology and Environmental Medicine Atlanta, GA 30333, pp-1-18, 2009

[21]. L D Claxton, T J Hughes, K T Chung, Using base-specific Salmonella tester strains to characterize the types of mutation induced by benzidine and benzidine congeners after reductive metabolism. Food and Chemical Toxicology 2001; 39(12):1253-1261

[22]. Kenneth C. Morton,2 Charles M. King,3 and Karl P. Baetcke, Metabolism of Benzidine to N-Hydroxy-N,N'-diacetylbenzidine and Subsequent Nucleic Acid Binding and Mutagenicity1, [Cancer Research 39, 3107-31031, 1979]

[23]. Marco Ciotti, Vijaya M Lakshmi,Glucoronidation of benzidineand its metabolites by its cDNA expressed human UDP glucoronosyl transferases and pH stability of Glucoronides,Carcinogenesis, vol 20,(10) pp 1963-1969, 1999

[24]. P Van Beleen, P Doleman, Significance and applications of microbial toxicity tests in assessing ecotoxicological risks of contaminants in soil or sediments, Natioinal Institute of Health and Environment Bilthoven ,The Netherlands, Report No 719102051. 1996.

[25]. Benzidine dyes metabolized to benzidine, Report on Carcinogens, Twelfth Edition, National Toxicology Program, Department of Health and Human Services http://ntp.niehs.nih.gov/go/roc12, pp-62-65, 2011

[26]. C. Pozo, M.V. Mart inez-Toledo, V. Salmerón, B. Rodelas, J. González-López, Effects of benzidine and benzidine analogues on the growth and nitrogenase activity of Azotobacter, Applied Soil Ecology 14 (2000) 183-190

[27]. Benzidine and its Toxicological Profile - A Water Pollutant from the Textile Dye Release, International Journal of Advanced Information Science and Technology (IJAIST) ISSN: 2319:2682 Vol.20, No.20, December 2013

[28]. S.D. Kalme, G.K. Parshetti, S.U. Jadhav, S.P. Govindwar, Biodegradation of benzidine based dye Direct Blue-6 by Pseudomonas desmolyticum NCIM 2112, Bioresource Technology xxx (2006) xxx-xxx

[29]. C. Pozo a, M.V. Mart' inez-Toledo a, B. Rodelas b, J. González-López, Response of soil microbiota to the addition of 3,3diaminobenzidine, Applied Soil Ecology 23 (2003) 119-126

[30]. Kimani Cynthia Muthoni, Microbial degradation of azo dyes in industrial effluents, Reg No: H12/3082/2010

[31]. M.Sudha, A.Saranya, Microbial degradation of Azo Dyes: A review, Int.J.Curr.Microbiol.App.Sci (2014) 3(2): 670-690

[32]. N. Manikandan, S. Surumbar Kuzhali and R. Kumuthakalavalli, Biodegradation of Textile Dye by Using Achromobacter xylosoxidans GRIRKNM11 Isolated from Dye Polluted Site, J Environmental Analytical Toxicology 2012, 2:8 http://dx.doi.org/10.4172/2161-0525.100016

[33]. B. Jalili, F. Nourbakhsh, M. Ghiasi, Kinetic approach to evaluate the effects of 3,3'-diamino- benzidine on N mineralization in soils, PLANT SOIL ENVIRON., 56, 2010 (9): 429-433

[34]. Patrícia Alexandra Degradation of dyes with microorganisms Studies with ascomycete yeasts, Costa Ferreira Ramalho Braga, Biology Department, University of Minho 2005 
[35]. Krishnaswamy, Veena Gayathri and Namasivayam Vasudevan, Enrichment of Phenol Degrading Moderately HalophilicBacterial Consortium from Saline Environment, Journal of Bioremediation \& Biodegradation, ISSN:2155-6199 JBRBD,pp 1-6,2010

[36]. J. Jayabarath, S. Asma Musfira, Biodegradation of Carbofuran Pesticide by Saline Soil Actinomycetes,International Journal of Biotechnology and Biochemistry ISSN 0973-2691 Volume 6 Number 2 (2010) pp. 187-192

[37]. Benedict C. Okeke, Tara Giblin, Reduction of perchlorate and nitrate by salt tolerant bacteria, Environmental Pollution 118 (2002) $357-363$

[38]. Mohandass Ramya Bhaskar Anusha ,Decolorization and biodegradation of Indigo carmine by a textile soil isolate Paenibacillus larvae, Biodegradation (2008) 19:283-291

[39]. Dimitry Yu. Sorokin, Sander van, Acetonitrile degradation under haloalkaline conditions by Natronocella acetinitrilica gen. nov., sp. nov., Microbiology (2007), 153, 1157-1164

[40]. Hongling Liu, Hongxia Yu , John P. Giesy, Tielian Xu and Yu Zhou, Response of antioxidant Parameters to 3,3'-DimethylBenzidine in Goldfish, (CarassiusAuratus) Liver Fersenius Environmental Bulletin, PSP Volume 18 - No 5a. Feb,2009

[41]. Vasudeo Sarwade, Kachru Gawai, Biodegradation of aniline by alkaliphilic strain Bacillus badius D1, IOSR Journal of Environmental Science, Toxicology and Food Technology (IOSR-JESTFT), e-ISSN: 2319-2402,p- ISSN: 2319-2399.Volume 8, Issue 5 Ver. II (May. 2014), PP 71-78

[42]. D. Kotresha G. M. Vidyasagar, Isolation and characterisation of phenol-degrading Pseudomonas aeruginosa MTCC 4996, World J Microbiol Biotechnol (2008) 24:541-547, DOI 10.1007/s11274-007-9508-2

[43]. Yuanyuan Qu $\bullet$ Ruijie Zhang • Fang Ma Jiti Zhou • Bin Yan, Bioaugmentation with a novel alkali-tolerant Pseudomonas strain for alkaline phenol wastewater treatment in sequencing batchreactor, World J Microbiol Biotechnol, (2011)DOI 10.1007/s11274-0110653-2

[44]. Kyung Han Kwon Sung Ho Yeom, Optimal microbial adaptation routes for the rapid degradation of high concentration of phenol, Bioprocess Biosyst Eng (2009) 32:435-442 DOI 10.1007/s00449-008-0263-z

[45]. Sumera Afzal Khan, Muhammad Hamayun, Influence of pH, temperature and glucose on biodegradation of 4-aminophenol by a novel bacterial strain, Pseudomonas sp. ST-4, African Journal of Biotechnology Vol. 8 (16), pp. 3827-3831, 18 August, 2009

[46]. Gursharan Singh a, Naveen Ahuja,Biobleaching of wheat straw-rich soda pulp with alkalophilic laccase from $\searrow$-proteobacterium JB: Optimization of process parameters using response surface methodology, Bioresource Technology (99) 7472-7479(2008)

[47]. UFZ, Helmholtz-Zentrum für Umweltforschung GmbH, Activity and Reaction Mechanism of the Initial Enzymatic Step Specifying the Microbial Degradation of 2,4-Dichlorophenoxyacetate, Eng. Life Sci. 7, (4), 311-321,2007

[48]. Urszula Guzik, Izabela Gre_n, Katarzyna Hupert-Kocurek, Danuta Wojcieszynska, Catechol 1,2-dioxygenase from the new aromatic compounds e Degrading Pseudomonas putida strain N6, International Biodeterioration \& Biodegradation 65 504-512 (2011)

[49]. Mei Rong Hu - Ya Peng Chao, Laccase-mediator system in the decolorization of Verent types of recalcitrant dyes, J Ind Microbiol Biotechnol pp 1-7. 2008 DOI 10.1007/s10295-008-0471-1

[50]. Junmin Li Zexin Jin, Binbin Yu, Isolation and characterization of aniline degradation slightly halophilic bacterium, Erwinia sp. Strain HSA 6, Microbiological Research Volume 165, Issue 5, 20 July 2010, Pages 418-426

[51]. José M. Molina-Guijarro, Juana Pérez, Detoxification of azo dyes by a novel pH-versatile, salt-resistant laccase from Streptomyces ipomoea, International Microbiology (2009) 12:13-21

[52]. F. J. O'neill, K. C. A. Bbromley-Challenor, Bacterial growth on aniline: Implications for the biotreatment of industrial waste water, Water. Res. Vol. 34, No. 18, pp. 4397-4409, (2000)

[53]. Thomas Maskow Sabine Kleinsteuber, Carbon and energy fluxes during haloadaptation of Halomonas sp. EF11 growing on phenol, Extremophiles (2004) 8:133-141 DOI 10.1007/s00792-003-0372-1

[54]. Qiong Jin, Zhongce Hu, Zanfang Jin, Biodegradation of aniline in an alkaline environment by a novel strain of the halophilic bacterium, Dietzia natronolimnaea JQ-AN, College of Biological and Environmental Engineering, Zhejiang University of Technology, Hangzhou 310032, PR China, 26 April 2012http://dx.doi.org/10.1016/j.biortech.2012.04.068,

[55]. Urania S. Zissi, Gerasimos C. Lyberatos, Kinetics of growth and aniline degradation by Stenotrophomonas maltophila, Water Environment Research Vol. 71, No. 1 (Jan. - Feb., 1999), pp. 43-49 